\title{
Temporal analysis of population genetic composition in the overexploited Japanese eel Anguilla japonica
}

\author{
Yu-San Han · Yu-Liang Sun · Yi-Fen Liao • \\ I-Chiu Liao · Kang-Ning Shen · Wann-Nian Tzeng
}

Received: 11 June 2008/Accepted: 27 August 2008/Published online: 17 September 2008

(C) Springer-Verlag 2008

\begin{abstract}
The Japanese eel has dramatically declined in Asia since the 1970s. Over the past two decades, glass eel productivity in Taiwan has decreased, but is highly variable among each year catch, though the cause for this is unknown. The impact of both population decline and instability on genetic diversity, however, is unknown. In this study, we investigated changes in allele frequencies of Japanese eel recruitment events over the past 20 years using six polymorphic microsatellite DNA loci. Specimens of glass eels were collected yearly from a single location in northern Taiwan from 1986 to 2007. Overall genetic differentiation among all samples was very low but significant $\left(F_{\mathrm{ST}}=0.002, P=0.002\right)$, and only 2 out of 120 pairwise tests were significant. The relationship between genetic and temporal distance showed a slight but insignificant correlation $\left(R^{2}=0.03, P=0.0504\right)$. There were no overall significant differences in allelic richness $(P=0.35)$ or genetic heterozygosity $(P=0.73)$ among annual recruitment events. No apparent loss of genetic diversity and occurrence of a genetic bottleneck for eel populations were observed. Estimates of the effective population size $\left(N_{\mathrm{e}}\right)$
\end{abstract}

Communicated by T. Reusch.

Y.-S. Han $(\bowtie)$ · Y.-L. Sun · Y.-F. Liao · K.-N. Shen ·

W.-N. Tzeng ( $\square)$

Institute of Fisheries Science, College of Life Science,

National Taiwan University, Taipei 106, Taiwan

e-mail: yshan@ntu.edu.tw

W.-N. Tzeng

e-mail: wnt@ntu.edu.tw

I-C. Liao

Department of Aquaculture,

College of Life and Resource Sciences,

National Taiwan Ocean University,

2 Pei-Ning Road, Keelung 202, Taiwan generally exceeded 500, although confidence intervals were very wide. While El Niño/Southern Oscillation (ENSO) events had little impact on genetic diversity, they may account for the annual fluctuation in glass eel catch. These results indicate long-term stability of genetic diversity in the Japanese eel with little evidence for sweepstakes recruitment.

\section{Introduction}

Fisheries management and conservation of commercially important species are directed to ensure sustainable exploitation and rely on knowledge of the target species. In this sense, genetic approaches have long been recognized as effective methods for stock identification in aquatic organisms (Ward 2000). Although the effects of overexploitation on species diversity and abundance are well documented, few empirical studies have investigated likely threats to the genetic diversity of marine fishes (Hauser et al. 2002). One reason may be due to the fact that even "overexploited" stocks usually consist of several million individuals, whereas population genetics theory suggests that only very small populations suffer significant loss of genetic diversity (Nei et al. 1975; Ryman et al. 1995). However, factors other than population size can alter allele frequencies. Hedgecock (1994) suggested that sweepstakes recruitment of marine organisms with high fecundity and type III survivorship curves (high juvenile mortality) could result in large variance of reproductive success, affecting temporal variation of allele frequencies and their effective population sizes $\left(N_{\mathrm{e}}\right)$. Furthermore, events such as climate change, shifts in oceanic currents, hurricanes and other natural disturbances may create 
unstable environments, which may also contribute to changes in allele frequencies (Allison et al. 2003).

The Japanese eel (Anguilla japonica Temminck \& Schlegel) is a temperate catadromous fish with a long migratory loop (Tsukamoto 1992, 2006; Tesch 2003). The silver adults leave continental rivers and swim more than $2000 \mathrm{~km}$ for about six months to the west of Mariana Islands to spawn and then die (Tsukamoto 2006). From their spawning grounds, the hatched larvae (leptocephali) drift with the North Equatorial Current (NEC), and then follow the Kuroshio Current (KC) for 4-6 months before reaching the coasts of Northeast Asia (Tzeng 1990; Cheng and Tzeng 1996). Because the Japanese eel is an important aquaculture species in Asia, great numbers of glass eels are caught in estuaries for cultivation, resulting in over-fishing (Tzeng 1985; Liao 2001). The Japanese eel population has been rapidly declining and is currently estimated to be less than $10 \%$ of 1970s level (Dekker 2003). In the rivers of Taiwan, Japanese eel population has also significantly decreased in past decades (Han and Tzeng 2006).

Population genetic structure is exhibited by the Japanese eel, which can be divided into southern and northern subpopulations in East Asia (Tseng et al. 2006). It is thought that stable oceanographic features return larvae to the rivers of their ancestors with little genetic exchanges between neighboring subpopulations (Sinclair 1988; Kettle and Haines 2006; Tseng et al. 2006). Therefore, genetic differentiation among annual recruits from the same location may be small. Tseng et al. (2003) reported no genetic differentiation of the Japanese glass eels in northern Taiwan over three consecutive years (1997-1999). However, Pujolar et al. (2006) found highly significant genetic differentiation among inter-annual or among intra-annual arrival recruits of the European eel Anguilla anguilla, indicating variance in reproductive success (genetic patchiness). Moreover, Maes et al. (2006) observed weak isolation by time (IBT) among intra-annual European eel recruits. To better understand the population genetic character of the Japanese eel, the inclusion of temporal sampling of recruits for a longer time period is necessary.

Because endangered species often exhibit decreased levels of genetic diversity (Frankham et al. 2002), which has been linked to reduced reproductive fitness (Madsen et al. 1999; Ebert et al. 2002), it is important to examine the extent of genetic change in intensely exploited species. Moreover, annual glass eel catch records indicate that the catch is not only declining but also varies greatly from year to year for unknown reasons (Fig. 1). This provides us a very good example to examine the relationship between resource decline/fluctuation and population genetic diversity. Here, we use microsatellite loci to assess genetic compositions in annual recruitment events of Japanese eels in a single estuary for 20 years. We explore (1) whether

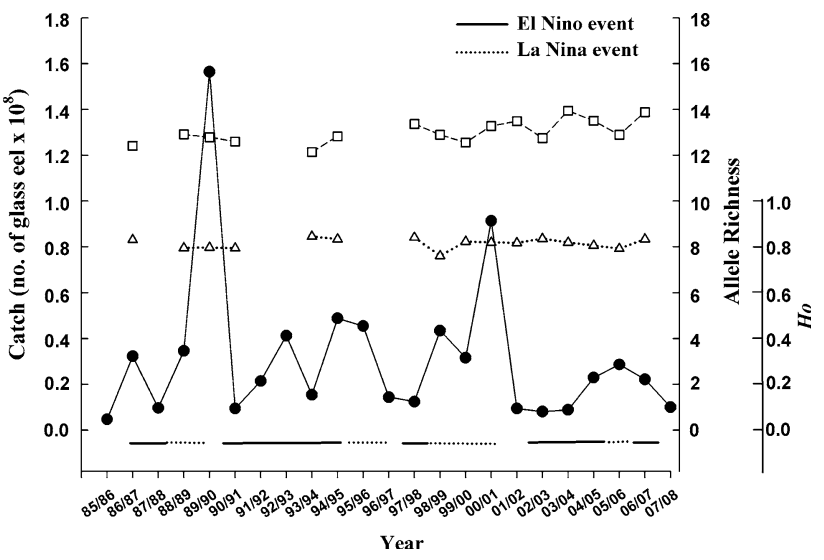

Fig. 1 Annual catch (filled circle), allelic richness (open square) and Ho (open triangle) of the Japanese glass eel from 1985 through 2008. The El Niño (filled line) and La Niña events (dashed line) were based on the Multivariate ENSO Index (MEI) from National Oceanic and Atmospheric Administration (NOAA), US Department of Commerce

genetic frequencies vary over the past two decades due to population decline/fluctuation or genetic patchiness, and (2) the possible role of $\mathrm{El} \mathrm{Niño/Southern} \mathrm{Oscillation}$ (ENSO) events on the glass eel catch and genetic diversity.

\section{Materials and methods}

\section{Sample collection}

Glass eels (juveniles of the Anguilla japonica) were collected by sampling monthly using a fyke net in northern Taiwan around Tanshui River from 1986 to 2007. In Taiwan, the arrival waves of glass eels usually start in October and end in March of the next year, which is defined to be an annual recruit. Our studies include samples mostly from the main arrival peak of glass eels in December and January. The annual recruitment events of 1987-1988, 1991-1992, 1992-1993, 1995-1996 and 1996-1997 were not collected. The glass eels caught with total lengths of 54-56 mm were immediately preserved in $95 \%$ ethanol until DNA extraction.

\section{DNA extraction}

A total of 957 glass eels were used for analysis. Genomic DNA was extracted using a DNA purification and extraction kit (Bioman Scientific Ltd.). Briefly, the ethanol was removed by evaporation before treatment. A piece of muscle weighing about $20 \mathrm{mg}$ was digested in $200 \mu \mathrm{l}$ of lysis buffer $(10 \mathrm{mM}$ Tris-HCl, $2 \mathrm{mM}$ EDTA, $10 \mathrm{mM}$ $\mathrm{NaCl}, 1 \%$ sodium dodecyl sulfate, $10 \mathrm{mg} / \mathrm{ml}$ dithiothreitol, $\mathrm{pH} 8.0)$ and $20 \mu \mathrm{l}$ of proteinase $\mathrm{K}\left(10 \mathrm{mg} \mathrm{ml}^{-1}\right)$ for $2 \mathrm{~h}$ at $60^{\circ} \mathrm{C}$ before grinding. The solution was then transferred to 
the spin column, washed by ethanol buffer, eluted with $50 \mu \mathrm{l}$ of elution buffer $(10 \mathrm{mM}$ Tris- $\mathrm{HCl}, \mathrm{pH} 8.5)$ and stored under $-20^{\circ} \mathrm{C}$ before polymerase chain reaction (PCR).

\section{PCR and genotyping}

Six microsatellite loci were selected from Genbank for high polymorphism and easy of use (Table 1). Microsatellite DNA was amplified via the PCR in a $25 \mu$ l volume with the following contents: $0.3 \mu \mathrm{l}$ of DNA template,

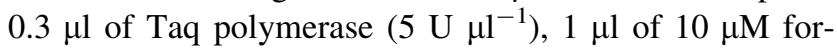
ward and reverse primers, $2.5 \mu \mathrm{l}$ of $10 \times$ PCR buffer, $0.6 \mu \mathrm{l}$ of $10 \mathrm{mM}$ dNTPs and $19.3 \mu \mathrm{l}$ of Milli-Q $\mathrm{H}_{2} \mathrm{O}$. Reverse primers contained FAM, TAMRA or HEX fluorescence labels for genotyping (Table 1). PCR amplification procedures were as follows: initial denaturation at $94^{\circ} \mathrm{C}$ for 3 min followed by 35 cycles of $94^{\circ} \mathrm{C}$ denaturation for $30 \mathrm{~s}$, $58-60^{\circ} \mathrm{C}$ annealing for $30 \mathrm{~s}, 72^{\circ} \mathrm{C}$ extension for $30 \mathrm{~s}$, and $72^{\circ} \mathrm{C}$ final extension for $10 \mathrm{~min}$. For genotyping, $1 \mu \mathrm{l}$ of PCR product was diluted with $12 \mu \mathrm{l}$ of Milli-Q $\mathrm{H}_{2} \mathrm{O}$ and fragment analysis was performed using a Megabase 1000 DNA analysis system (Amersham Biosciences). Scoring of data was performed by Genetic Profiler ${ }^{\mathrm{TM}}$ Version 2.0 (Amersham Biosciences) and the sizes of each allele were inspected visually.

\section{Data analysis}

The observed numbers of alleles $(n a)$, effective allele number $(n e)$, observed $\left(H_{\mathrm{o}}\right)$ and expected $\left(H_{\mathrm{e}}\right)$ heterozygosities as well as deviations from Hardy-Weinberg equilibrium (HWE) were independently calculated for each locus using ARLEQUIN vers. 3.1 software (Schneider et al. 2000). Multilocus estimations of $H_{\mathrm{o}}$ and $H_{\mathrm{e}}$ for each annual recruit were calculated as well. Pairwise Wright's fixation indices, $F_{\mathrm{ST}}$, were calculated using FSTAT vers. 3.9.5 (Goudet 1995) and the significance levels were adjusted by a sequential Bonferroni correction (Weir and Cockerham 1984; Rice 1989). Computation of allelic richness for specified sample sizes was based on the rarefaction method (Hurlbert 1971) using FSTAT vers. 3.9.5. The significant differences in allelic richness or heterozygosity among annual recruitment events were tested using a nonparametric Wilcoxon signed-ranks test. Pairwise Nei's (1983) unbiased distances $\left(D_{\mathrm{A}}\right)$ were calculated using DISPAN and visualized by multidimensional scaling (MDS) in STATISTICA v. 6.0 (StatSoft). The correlations between genetic distance $\left[F_{\mathrm{ST}} /\left(1-F_{\mathrm{ST}}\right)\right]$ and temporal distance among pairwise comparisons of inter-annual recruitment events were performed by Mantel test (Mantel 1967). Bottlenecks were inferred for each annual recruitment events under the assumption of mutation-drift equilibrium by either IAM or SMM models using the program BOTTLENECK version 1.2.02 (Cornuet and Luikart 1996). The allele dropout and null alleles for each annual recruitment events were tested using MicroChecker version 2.2.3 (Van Oosterhout et al. 2004).

The effective population size $\left(N_{\mathrm{e}}\right)$ was estimated using NEESTIMATOR version 1.3 (Peel et al. 2004) with moments based approaches according to Waples (1989). This temporal method assumes models with closed populations and assesses fluctuations in allele frequencies between two temporal samples separated by a known number of generations. We do not know the degree of possible gene inflow from other potential source populations. However, the gene flow is likely to be very small based on Tseng et al. (2006). Average generation length over time was calculated to 5.5 years for Japanese eel in Taiwan region based on Han et al. (unpublished data).

Table 1 Characteristics of six microsatellite DNA loci in A. japonica, including repeat motif, primer sequence, annealing temperature, GenBank accession no. and fluorescence label

\begin{tabular}{|c|c|c|c|c|c|}
\hline Locus & Repeat motifs & Primer sequence $\left(5^{\prime}-3^{\prime}\right)$ & $\begin{array}{l}\text { Annealing } \\
\text { Temp }\left({ }^{\circ} \mathrm{C}\right)\end{array}$ & Accession no. & $\begin{array}{l}\text { Fluorescence } \\
\text { (reverse) }\end{array}$ \\
\hline AJMS-3 & (GT)n & $\begin{array}{l}\text { F:GGT ATG AAT GCA GGC GTT TAT G } \\
\text { R:GCA ACC GAT TTG ATC TCC AG }\end{array}$ & 60 & AJ297601 & 5'TAMRA \\
\hline AJMS-5 & (GT)n & $\begin{array}{l}\text { F:CCT TCA GAT TGC TAG CAC } \\
\text { R:CGG AGT CTA ATT GTC TCC TC }\end{array}$ & 58 & AJ297602 & $5^{\prime} \mathrm{HEX}$ \\
\hline AJMS-6 & (GT)n & $\begin{array}{l}\text { F:ACA GAG CCA GAC AAA CAG AC } \\
\text { R:GGT CAG CAA GCA AAA CGA AC }\end{array}$ & 58 & AJ297603 & $5^{\prime} \mathrm{HEX}$ \\
\hline AJM-1 & (GT)n & $\begin{array}{l}\text { F:AGT AAA GAG TCC CAC GCA TTC } \\
\text { R:AAG GTG GAT TTT TGC TGG CTC }\end{array}$ & 60 & AM062762 & 5'TAMRA \\
\hline AjTR-12 & $(\mathrm{GA}) \mathrm{n}$ & $\begin{array}{l}\text { F:AAC GTT AGT CCC TAG GTT CC } \\
\text { R:TAA GGG TGT TAT ATG TTC AG }\end{array}$ & 58 & AB051084 & 5'FAM \\
\hline AjTR-37 & (GT)n & $\begin{array}{l}\text { F:AGA CCT TAT GTC ACC TTA TGC T } \\
\text { R:AAG ATG TTA AAT TCA ATT GTG C }\end{array}$ & 58 & AB051094 & $5^{\prime} \mathrm{FAM}$ \\
\hline
\end{tabular}


The El Niño/La Niña events are defined based on Climate Prediction Center of National Oceanic and Atmospheric Administration (NOAA), US Department of Commerce using Multivariate El Niño/Southern Oscillation (ENSO) Index (MEI) (http://www.cpc.ncep. noaa.gov/ products/analysis_monitoring/ ensostuff/ensoyears. shtml).

\section{Results}

Genetic diversity among recruitment events

We used a total of six polymorphic microsatellite loci to screen 16 annual recruitment events of the Japanese eel (Table 2). All loci were moderately to highly polymorphic such that the total number of alleles ranged from 9 in locus AJMS-3 to 35 in locus AjTR-12 with a mean of 24.3. There was one private allele found in the samples of years 19931994, 1999-2000 and 2004-2005, two private alleles found in the samples of years 2001-2002 and 2003-2004 and three private alleles found in the samples of years 19971998 and 2000-2001. Observed and expected heterozygosities of each sample ranged from 0.5417 to 0.9394 (mean 0.8151 ) and from 0.5149 to 0.9453 (mean 0.8473 ), respectively. HWE test showed that only 3 out of 96 $(3.13 \%)$ significantly deviated after Bonferroni corrections (Table 2). They were scattered in the loci of AJM-1 of year 1998-1999 and AjTR-12 of years 1988-1989 and 19992000 without locus- or recruit-specific pattern.

An allelic dropout was not found in any of the 16 annual recruitment events tested by Micro-Checker. Null alleles, however, were identified in 12 out of 96 tests in AJM-1 of years 1988-1989, 1990-1991, 1998-1999 and 2003-2004, AjTR-12 of years 1988-1989, 1989-1990, 1999-2000 and 2000-2001, AJMS-5 of years 1990-1991, 1993-1994, 2001-2002 and AjTR-37 of year 2004-2005 without locusor recruit-specific pattern.

There were no overall significant differences in allelic richness $(P=0.35)$ or genetic heterozygosity $(P=0.73)$ among annual recruitment events. The time series of both allelic richness and genetic heterozygosity were stable (Fig. 1). Significant differences between allelic richness of recruitment events, however, were found in 13 out of the 120 pairwise comparisons. Six of them occurred between year 2003-2004 and years 1986-1987, 19891990, 1993-1994, 1998-1999, 2000-2001 and 20022003. The other pairs were scattered without recruit-specific pattern. Significant differences between genetic heterozygosity of recruitment events were only found between year 2001-2002 and 2005-2006. No correlation between ENSO events and allelic richness or between ENSO events and genetic heterozygosity can be found. Tests for bottlenecks were not significant and showed normal L-shaped distributions in mode-shift for each annual recruitment events.

Genetic differentiation among recruitment events

Overall genetic differentiation among all samples was very low but significant $\left(F_{\mathrm{ST}}=0.002, P=0.002\right)$ (Table 3$)$. Pairwise $F_{\mathrm{ST}}$ comparisons were significant only in 2 out of 120 tests between years 1986-1987 and 2004-2005 and between years 1999-2000 and 2004-2005 (Table 3).

An MDS showed no evidence for temporal grouping or a specific pattern (Fig. 2). A temporal Mantel test revealed a slight but insignificant positive correlation between differences in time of recruitment in years and $F_{\mathrm{ST}} /\left(1-F_{\mathrm{ST}}\right)$ $\left(R^{2}=0.03, P=0.054\right)$ (Fig. 3).

Eel catch and $\mathrm{Ne}$ analysis

There were no significant correlations between eel catch and observed heterozygosity $\left(R^{2}=0.07, P=0.30\right)$ or between eel catch and allelic richness $\left(R^{2}=0.02\right.$, $P=0.63$ ). The years of abundant catch (years 1989-1990, 1995-1996, 1998-1999, 2000-2001 and 2004-2005) were usually accompanied with La Niña events, while the years of poor harvest (years 1987-1988, 1990-1991, 1993-1994, 1997-1998, 2002-2003 and 2003-2004) were usually during El Niño events, although there were also La Niña events associated with low catch (year 1996-1997) and El Niño events associated with high catch (year 1994-1995) (Fig. 1).

The effective population size $\left(N_{\mathrm{e}}\right)$ of the Japanese eel, estimated using Waples (1989) standard temporal method over year 1986-1987 to 1997-1998, spanning about two

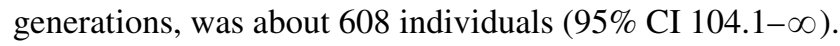
The estimated $N_{\mathrm{e}}$ over the whole time period (year 19861987 to 2006-2007), spanning approximately 4 genera-

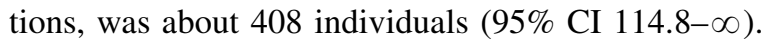

\section{Discussion}

While the Japanese eel shows spatial genetic differentiation throughout its range (Tseng et al. 2006), we find that genetic differentiation is temporally stable at a single location. The overall $F_{\mathrm{ST}}$ value among 16 recruitment events in the past 20 years is very low. Pairwise $F_{\text {ST }}$ tests indicate little genetic differentiation among annual recruitment events, as only 2 out of 120 were significant. The genetic patchiness found in the European eel, possibly a result of variance in reproductive success, is not found in the Japanese eel. This suggests higher temporal genetic differentiation in the European eel. For marine species, dispersal during the larval phase is often important in shaping population genetic structure, and ocean 


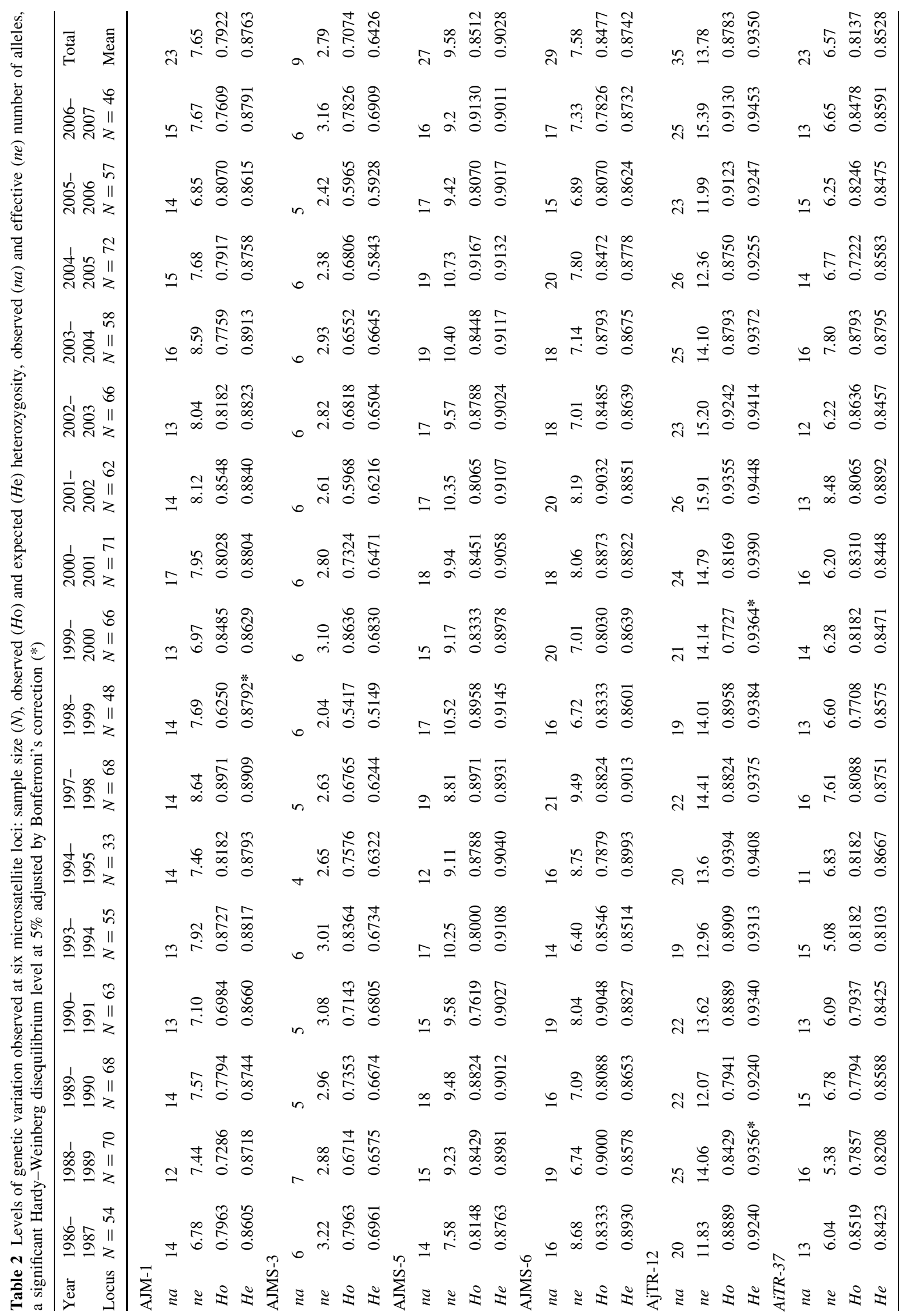




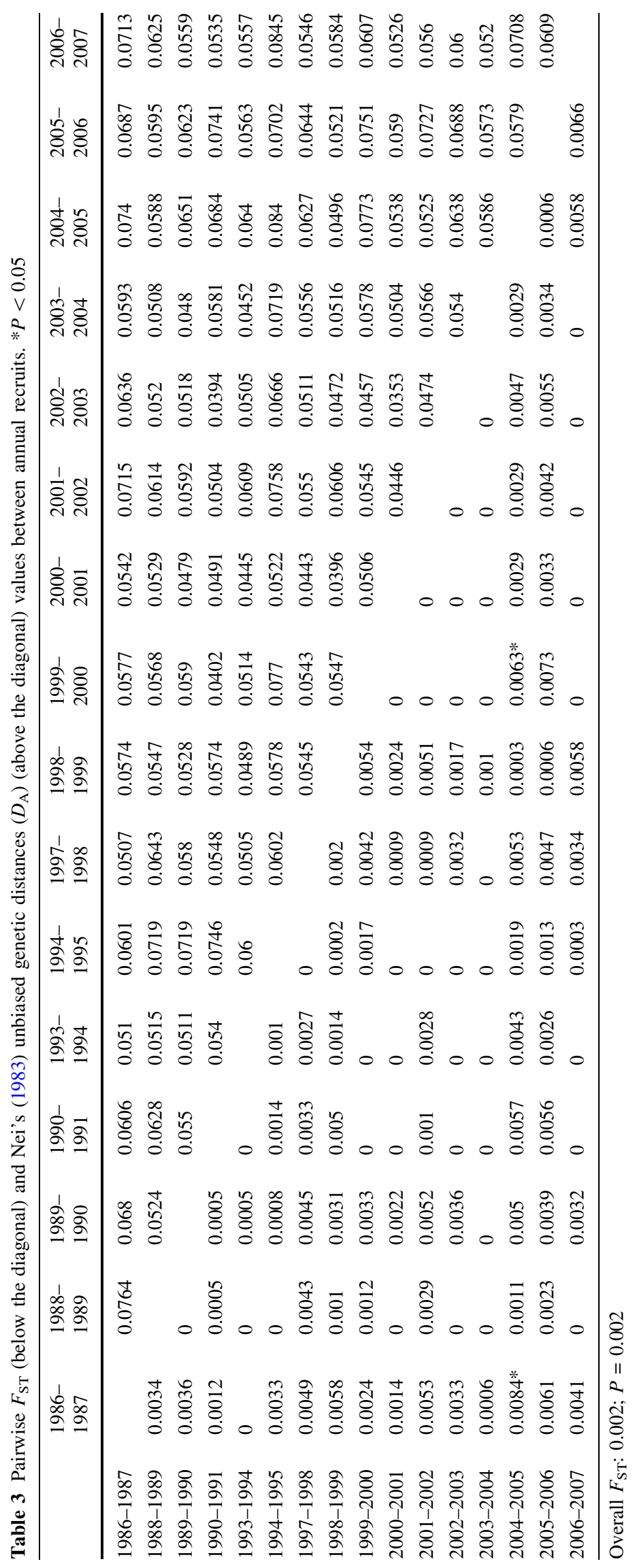




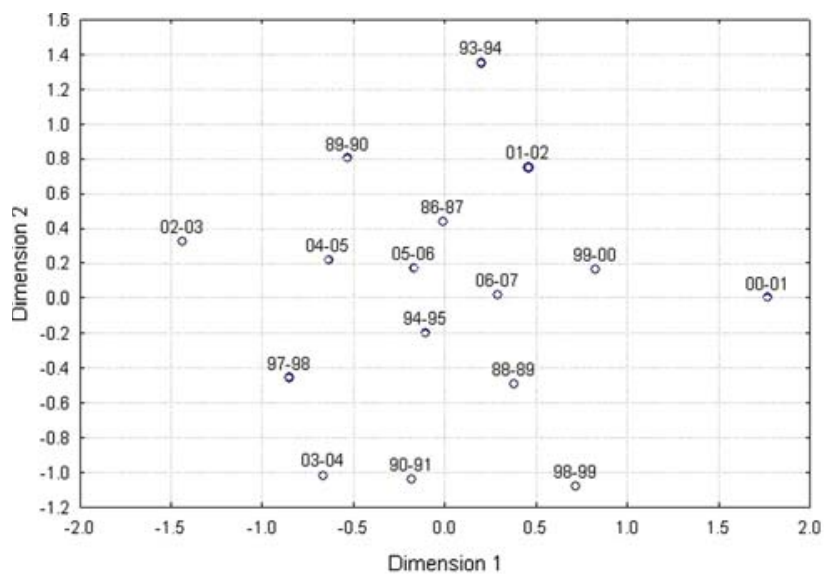

Fig. 2 Multidimensional scaling analysis of the matrix of pairwise chord distance for 16 annual recruitment events based on six microsatellite loci. Stress $=0.267$

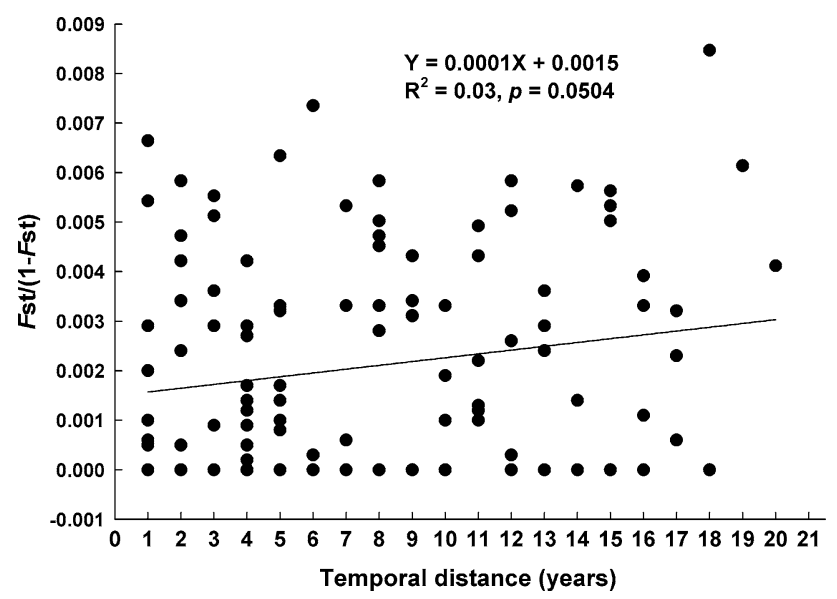

Fig. 3 Regression of genetic differentiation $\left[F_{\mathrm{ST}} /\left(1-F_{\mathrm{ST}}\right)\right]$ at microsatellites on temporal distance in years between recruitment events using Mantel test

currents play a central role in larval transport (Sponaugle et al. 2002; Fisher 2005). The migration distances for the European and Japanese eels range 4,000-8,000 and 2,000$3,500 \mathrm{~km}$, respectively (Aoyama et al. 2003; Tesch 2003). The larval dispersal time for the European and Japanese eels range 14-16 and 4-6 months, respectively (Cheng and Tzeng 1996; Wang and Tzeng 2000). The time and distance required for dispersing larvae and migrating adults are longer in European than in Japanese eels. The oceanic variations that the European eel faces should be more complicated than those faced by the Japanese eel, possibly resulting in higher genetic differentiation in the European eel.

The interval between peaks in catch averages 5-6 years, which seemed to match the generation time of the Japanese eel in Taiwan, with 4-5 years of yellow eel stage (Han et al., unpublished data) plus one year of spawning migration and larval drifting (Cheng and Tzeng 1996;
Tsukamoto 2006). The fluctuation in annual eel catch, however, showed no effect on genetic diversity, but seemed to be partially affected by environmental factors such as ENSO events. Kimura et al. (2001) found that movement of the salinity front in the spawning ground, which is associated with ENSO, may limit the success of larval transport from the NEC to East Asia. The glass eel catch in Japan was also generally low during El Niño events.

The Japanese eel exhibits some levels of latitudinal genetic structuring (Tseng et al. 2006). Larval recruitment to its ancestral estuary may depend upon the starting location of the spawning ground as suggested by Kettle and Haines (2006). Silver eel spawners from different locations might develop strategies to migrate and spawn in particular regions. The movement of water packets in oceanic current systems may show high spatial and temporal autocorrelation, which restricts the degree of independent larval trajectories (Gaines et al. 2003; Siegel et al. 2003). The hatched leptocephali in different depths, latitudes and longitudes from the spawning region are preferentially transported back to certain latitude ranges where their parents were located. This may explain the low gene flow between neighboring populations of the Japanese eel found by Tseng et al. (2006). In the present study, although the real mixing rate between eel populations of Taiwan and other areas is unknown, it can be regarded as a closed population for $N_{\mathrm{e}}$ estimation. The $N_{\mathrm{e}}$ thus determines the level of inbreeding and the amount of genetic variation lost from populations due to random genetic drift. Reliable estimates of $N_{\mathrm{e}}$ in natural populations are important to evaluate whether threatened populations are able to maintain sufficient genetic variation to adapt to future environmental changes (Franklin 1980). Effective population sizes in the range of 500-5,000 have been suggested as necessary to maintain an evolutionary potential of natural populations (Frankham et al. 2002). In the present study, the estimated $N_{\mathrm{e}}$ for the Japanese eel was around 500, an indication that such populations are outside immediate danger of losing their evolutionary potential (Franklin 1980). The highly fluctuated annual production of the Japanese glass eel in Taiwan over the past 20 years did not result in bottleneck effects. The stable allelic richness and heterozygosity in the past 20 years also support no loss of microsatellite diversity in overexploited Japanese eel.

In the present study, there were no overall significant differences in either allelic richness or genetic heterozygosity among annual recruitment events. However, the temporal Mantel test revealed a marginal positive correlation between differences in time of recruitment in years and $F_{\mathrm{ST}}$, suggesting a slight year-to-year variation. It is unclear whether this is caused by yearly variation in reproductive success, or, alternatively, by cumulative genetic variation. 
To validate this event, older eel samples before 1980s are needed, but none are currently available.

In conclusion, our results clearly indicate generally stable genetic composition of the Japanese eel in a single location over the past 20 years. However, the decline of eel abundance began in the 1970s (Dekker 2003; Tatsukawa 2003), about 10 years before its genetic composition was assayed. The possible impact of a $90 \%$ decline in population size before 1980s on its genetic diversity cannot be excluded. Accordingly, regulation should be implemented to prevent further decline of this valuable resource.

Acknowledgments The authors express their gratitude to Ms. H.Y. Teng, Drs. C.W. Chang and Y.T. Wang for collecting specimens from Taiwan. Research fundings were provided by the National Science Council of the Executive Yuan, Taiwan (NSC 95-2313-B-002-070, NSC 95-2313-B-002-119 and NSC 97-2621-B-002-011). Experiments were complied with the current laws of the Taiwan, ROC.

\section{References}

Allison GW, Gaines SD, Lubchenco J, Possingham HP (2003) Ensuring persistence of marine reserves: catastrophes require adopting an insurance factor. Ecol Appl 13(Suppl 1):8-24. doi: 10.1890/1051-0761(2003)013[0008:EPOMRC]2.0.CO;2

Aoyama J, Wouthuyzen S, Miller MJ, Inagaki T, Tsukamoto K (2003) Short-distance spawning migration of tropical freshwater eels. Biol Bull 204:104-108. doi:10.2307/1543500

Cheng PW, Tzeng WN (1996) Timing of metamorphosis and estuarine arrival across the dispersal range of the Japanese eel Anguilla japonica. Mar Ecol Prog Ser 131:87-96. doi:10.3354/ meps 131087

Cornuet JM, Luikart G (1996) Description and power analysis of two tests for detecting recent population bottlenecks from allele frequency data. Genetics 144:2001-2014

Dekker W (2003) Did lack of spawners cause the collapse of the European eel, Anguilla anguilla? Fish Manag Ecol 10:365-376. doi:10.1111/j.1365-2400.2003.00352.x

Ebert D, Haag C, Kirkpatrick M, Riek M, Hottinger J, Pajunen I (2002) A selective advantage to immigrant genes in a Daphnia metapopulation. Science 295:485-488. doi:10.1126/science. 1067485

Fisher R (2005) Swimming speeds of larval coral reef fishes: impacts on self-recruitment and dispersal. Mar Ecol Prog Ser 285:223232. doi: $10.3354 / \mathrm{meps} 285223$

Frankham R, Ballou JD, Briscoe DA (2002) Introduction to conservation genetics. Cambridge University Press

Franklin IR (1980) Evolutionary changes in small populations. In: Soule ME, Wilcox BA (eds) Conservation biology: an evolutionary-ecological perspective. Sinauer Associates, Sunderland, pp $135-150$

Gaines SD, Gaylord B, Largier JL (2003) Avoiding current oversights in marine reserve design. Ecol Appl 13:32-46. doi:10.1890/ 1051-0761(2003)013[0032:ACOIMR]2.0.CO;2

Goudet J (1995) FSTAT version 1.2: a computer program to calculate $F$-statistics. J Hered 86:485-486

Han YS, Tzeng WN (2006) Sex ratio as a means of resource assessment for the Japanese eel Anguilla japonica: a case study in the Kaoping River of Taiwan. Zool Stud 45:255-263

Hauser L, Adcock GJ, Smith PJ, Ramírez JHB, Carvalho GR (2002) Loss of microsatellite diversity and low effective population size in an overexploited population of New Zealand snapper (Pagrus auratus). Proc Natl Acad Sci USA 99:11742-11747. doi:10.1073/pnas.172242899

Hedgecock D (1994) Does variance in reproductive success limit effective populations sizes of marine organisms? In: Beaumont AR (ed) Genetics and evolution of aquatic organisms. Chapman and Hall, London, pp 122-134

Hurlbert SH (1971) The nonconcept of species diversity: a critique and alternative parameters. Ecology 52:577-586. doi:10.2307/ 1934145

Kettle AJ, Haines K (2006) How does the European eel (Anguilla anguilla) retain its population structure during its larval migration across the North Atlantic Ocean? Can J Fish Aquat Sci 63:90-106. doi:10.1139/f05-198

Kimura S, Inoue T, Sugimoto T (2001) Fluctuation in the distribution of low-salinity water in the North Equatorial Current and its effect on the larval transport of the Japanese eel. Fish Oceanogr 10:51-60. doi:10.1046/j.1365-2419.2001.00159.x

Liao IC (2001) A general review on aquaculture in Asia: a focus on anguillid eel. In: Liao IC. (complied) Keynote Addresses, The 5th and 6th Asian Fisheries Forums. AFS Special Publication No. 11, pp 39-54

Madsen T, Shine R, Olsson ML, Wittzell H (1999) Restoration of an inbred adder population. Nature 402:34-35. doi:10.1038/46941

Maes GE, Pujolar JM, Hellemans B, Volckaert FAM (2006) Evidence for isolation by time in the European eel (Anguilla anguilla L.). Mol Ecol 15:2095-2107. doi:10.1111/j.1365-294X.2006.02925.x

Mantel N (1967) The detection of disease clustering and a generalized regression approach. Cancer Res 27:209-220

Nei M (1983) Genetic polymorphism and the role of mutation in evolution. In: Nei M, Koehn R (eds) Evolution of genes and proteins. Sinauer Associates, Sunderland, pp 165-190

Nei M, Maruyama T, Chakraborty R (1975) The bottleneck effect and genetic variability in populations. Evol Int J Org Evol 29:1-10. doi: $10.2307 / 2407137$

Peel D, Ovenden JR, Peel SL (2004) NEESTIMATOR: Software for estimating effective population size, version 1.3. Queensland Government, Department of Primary Industries and Fisheries, Brisbane, Queensland

Pujolar JM, Maes GE, Volckaert FAM (2006) Genetic patchiness among recruits in the European eel Anguilla anguilla. Mar Ecol Prog Ser 307:209-217. doi:10.3354/meps307209

Rice WR (1989) Analyzing tables of statistical tests. Evol Int J Org Evol 43:223-225. doi:10.2307/2409177

Ryman N, Utter F, Laikre L (1995) Protection of intraspecific biodiversity of exploited fishes. Rev Fish Biol Fish 5:417-446. doi:10.1007/BF01103814

Schneider S, Roessli D, Excoffier L (2000) Arlequin: a software for population genetics data analysis. vers 2.000. Genetics and Biometry Lab, Geneva, Department of Anthropology, University of Geneva

Sinclair M (1988) Marine populations: an assay on population regulation and speciation. University of Washington Press, Seattle

Siegel DA, Kinlan BP, Gaylord B, Gaines S (2003) Lagrangian descriptions of marine larval dispersion. Mar Ecol Prog Ser 260:83-96. doi:10.3354/meps260083

Sponaugle S, Cowen RK, Shanks A, Morgan SG, Leis JM, Pineda JS et al (2002) Predicting self-recruitment in marine populations: biophysical correlates and mechanisms. Bull Mar Sci 70:341-375

Tatsukawa K (2003) Eel resources in East Asia. In: Aida K, Tsukamoto K, Yamauchi K (eds) Eel biology. Springer-Verlag Press, Tokyo, pp 293-298

Tesch FW (2003) The eel. Blackwell Science, Oxford

Tseng MC, Tzeng WN, Lee SC (2003) Historical decline in the Japanese eel Anguilla japonica in northern Taiwan inferred from genetic variations. Zool Stud 42:556-563 
Tseng MC, Tzeng WN, Lee SC (2006) Population genetic structure of the Japanese eel Anguilla japonica in the northwest Pacific Ocean: evidence of non-panmictic populations. Mar Ecol Prog Ser 308:221-230. doi:10.3354/meps308221

Tsukamoto K (1992) Discovery of the spawning area for Japanese eel. Nature 356:789-791. doi:10.1038/356789a0

Tsukamoto K (2006) Spawning of eels near a seamount. Nature 439:929. doi:10.1038/439929a

Tzeng WN (1985) Immigration timing and activity rhythms of the eel, Anguilla japonica, elvers in the estuary of northern Taiwan, with emphasis on environmental influences. Bull Jap Soc Fish Oceanogr 47(48): 11-28

Tzeng WN (1990) Relationship between growth rate and age at recruitment of Anguilla japonica elvers in a Taiwan estuary as inferred from otolith growth increments. Mar Biol (Berl) 107:75-81. doi:10.1007/BF01313244
Van Oosterhout C, Hutchinson WF, Wills DPM, Shipley P (2004) MICRO-CHECKER: software for identifying and correcting genotyping errors in microsatellite data. Mol Ecol Notes 4:535538. doi:10.1111/j.1471-8286.2004.00684.x

Wang CH, Tzeng WN (2000) The timing of metamorphosis and growth rates of American and European eel leptocephali-a mechanism of larval segregative migration. Fish Res 46:191205. doi:10.1016/S0165-7836(00)00146-6

Waples RS (1989) A generalized approach for estimating effective population size from temporal changes in allele frequency. Genetics 121:379-391

Ward RD (2000) Genetics in fisheries management. Hydrobiologia 420:191-201. doi:10.1023/A:1003928327503

Weir BS, Cockerham CC (1984) Estimating F-statistics for the analysis of population structure. Evol Int J Org Evol 38:13581370. doi:10.2307/2408641 